\title{
Incidence, Phenotypic Features and Molecular Genetics of Kallmann Syndrome in Finland
}

\author{
Eeva-Maria Laitinen ${ }^{1,2+}$, Kirsi Vaaralahti ${ }^{1,2+}$, Johanna Tommiska ${ }^{1,2}$, Elina Eklund ${ }^{2}$, Mari Tervaniemi ${ }^{2}$, Leena Valanne ${ }^{3}$ \\ and Taneli Raivio ${ }^{1,2^{*}}$
}

\begin{abstract}
Background: Kallmann syndrome (KS), comprised of congenital hypogonadotropic hypogonadism (HH) and anosmia, is a clinically and genetically heterogeneous disorder. Its exact incidence is currently unknown, and a mutation in one of the identified KS genes has only been found in $~ 30 \%$ of the patients.

Methods: Herein, we investigated epidemiological, clinical, and genetic features of KS in Finland.

Results: The minimal incidence estimate of KS in Finland was 1:48 000, with clear difference between males (1:30 $000)$ and females (1:125 000) $(p=0.02)$. The reproductive phenotype of 30 probands (25 men; 5 women) ranged from severe $\mathrm{HH}$ to partial puberty. Comprehensive mutation analysis of all 7 known KS genes (KAL1, FGFR1, FGF8, PROK2, PROKR2, CHD7, and WDR11) in these 30 well-phenotyped probands revealed mutations in KAL1 (3 men) and FGFR1 (all 5 women vs. 4/25 men), but not in other genes.

Conclusions: Our results suggest that Finnish KS men harbor mutations in gene(s) yet-to-be discovered with sexdependent penetrance of the disease phenotype. In addition, some KS patients without CHD7 mutations display CHARGE-syndrome associated phenotypic features (e.g. ear or eye anomalies), possibly implying that, in addition to CHD7, there may be other genes associated with phenotypes ranging from KS to CHARGE.
\end{abstract}

\section{Introduction}

Kallmann syndrome (KS; MIM\# 147950), a combination of congenital hypogonadotropic hypogonadism $(\mathrm{HH}$; MIM\# 146110) and decreased/absent sense of smell, results from disturbed intrauterine migration of gonadotropin-releasing hormone $(\mathrm{GnRH})$ neurons from the olfactory placode to the hypothalamus [1-3]. Patients with KS usually lack puberty, but the reproductive phenotype may vary from severe hypogonadism (cryptorchidism or micropenis in male infants) to reversal of hypogonadotropism later in life [4,5]. Associated phenotypic features include cleft lip/palate, hearing impairment, dental agenesis, limb anomalies, renal agenesis, and mirror movements [6]. The incidence estimates of KS are scarce and variable, and the condition appears to be 3-5 times more frequent in men [6-8].

\footnotetext{
* Correspondence: taneli.raivio@helsinki.fi

† Contributed equally

${ }^{1}$ Children's Hospital, Helsinki University Central Hospital, University of Helsinki, Fl-00029 Helsinki, Finland

Full list of author information is available at the end of the article
}

KS is genetically heterogeneous, and the majority of cases ( $60 \%)$ present as sporadic cases (only one person affected in the family). In familial KS, autosomal recessive, autosomal dominant, and X-chromosomal recessive inheritance have been described [9]. Oligogenic mode of inheritance has also been suggested [10-13]. The genes involved in the etiology of KS are KAL1 [14,15], FGFR1 [16], FGF8 [11], PROK2 [13,17], PROKR2 [13,17], and WDR11 [18]. A monoallelic mutation in FGFR1 underlies approximately $10 \%$ of KS cases [16]. Consistent with variable expressivity of FGFR1 mutations, the mutation carriers may also display spontaneous fertility [16,19-21], and loss-of-function mutations in FGFR1 are found in $7 \%$ of patients with congenital $\mathrm{HH}$ but reportedly normal sense of smell [5]. In addition, mutations in CHD7, underlying over $60 \%$ of CHARGE syndrome (coloboma, heart defects, choanal atresia, retarded growth and development, genital abnormalities, and ear anomalies; MIM\# 214800) [22,23], have also shown to cause KS. To date, a molecular genetic diagnosis is attained in only approximately $30 \%$ of KS patients

\section{Biomed Central}


$[24,25]$, which implies the existence of additional genes underlying KS.

Here we provide a nationwide minimal incidence estimate of KS in Finland, describe the phenotypic and molecular genetic features of a representative series of Finnish KS patients, and characterize the functional effects of novel FGFR1 missense mutations.

\section{Materials and methods}

\section{Data sources}

Discharge registers of all 5 university hospitals in Finland were queried by the International Classification of Disease (ICD) edition 10 and 9 (ICD-10, -9) codes for hypogonadotropic hypogonadism (E23.04 and 253.4, respectively) covering the years from 1996 to 2007. Among the query results, in any case of hypogonadotropic hypogonadism, the medical charts were manually revised, and all patients of Finnish origin who had been diagnosed with $\mathrm{KS}$ on the basis of isolated gonadotropin deficiency without an organic cause, and anosmia or hyposmia, were identified. Of note, anosmia or hyposmia had been diagnosed on the basis of anamnestic information, olfactometry, or by the inability to recognize familiar odors such as coffee. All except one (excluded from further calculations), were born between 1976 and 1987. Thus the final series of hereby identified KS patients reflects the number of KS patients born in Finland between 1976 and 1987. To estimate a national incidence of KS, this number of KS patients was compared to the number of live-born children in Finland between 1976 and 1987 (Statistics Finland register database at http://pxweb2.stat.fi/database/StatFin/vrm/synt/ synt_en.asp).

\section{Clinical and molecular genetic evaluation of the patients Medical history and clinical examination}

The patients willing to participate in the molecular genetic part of this study were enrolled from the 5 different university hospitals in Finland, and were asked for a detailed medical history including history of cryptorchidism, micropenis, prior pubertal development, prior treatment, associated phenotypes, and the sense of smell, and these data were verified by medical chart review. Patients were also asked for the presence or absence of KS, normosmic $\mathrm{HH}$, infertility, isolated anosmia or hyposmia, cryptorchidism, delayed puberty, dental agenesis, or cleft lip and palate in their family members and relatives. In retrospect, all adult patients fulfilled the following criteria: 1) absent or incomplete pubertal development by the age of 18 yrs, 2) low circulating basal sex steroid levels in association with inappropriately low or normal gonadotropin levels, and subnormal or normal response to GnRH stimulation test, 3) otherwise normal anterior pituitary function, 4) anosmia or hyposmia based on either anamnestic information, formal testing (e.g. olfactometry), or testing with familiar odors, and 5) no organic cause for their condition. In addition to adult patients, 12-18 yr-old-patients with unequivocal signs of severe congenital $\mathrm{HH}$ (history of cryptorchisim and/or micropenis), absent puberty, and anosmia/hyposmia were enrolled.

The participants underwent a complete physical examination, including mirror movement assessment, and measurement of testicular volume with a ruler (length $x$ width $^{2} \times 0.52$ ). Olfaction was assessed with the 40-item smell testing (University of Pennsylvania Smell Identification Test, UPSIT, Sensonics Inc, Haddon Heights, $\mathrm{NJ}$ ), and individuals scoring $<5^{\text {th }}$ percentile for age in UPSIT, were classified as anosmic. A blood sample was drawn for DNA extraction. Renal structures were assessed by abdominal ultrasound scan. The following brain magnetic resonance imaging (MRI) protocol was used to visualize the olfactory bulbs, sulci, and inner ears (corresponding sequences in 1.5 and 3 tesla units): axial T2 FSE and FLAIR images of the whole brain, coronal T2 FSE with $3 \mathrm{~mm}$ slice thickness starting from the anterior surface of the frontal lobe, 3D MPR sagittal images $(1 \times 1 \mathrm{~mm})$ covering the whole head with coronal reconstructions, 3D T2-weighted thin slices (CISS, DRIVE, voxel size $0.3-0.5 \mathrm{~mm} \times 3$ ) axial images from the region of the inner ear. No contrast medium was used.

The family members willing to participate were contacted and recruited with the permission of the proband, and they filled in a questionnaire or were interviewed by telephone for prior pubertal development, fertility, associated phenotypes, and the sense of smell. A blood sample was drawn for DNA extraction.

\section{Mutation analysis}

Genomic DNA from peripheral blood leukocytes was extracted, and the coding exons and exon-intron boundaries of 8 genes [KAL1 (MIM\# 308700; RefSeq NM_000216.2, gi:119395745), FGFR1(MIM\# 136350; RefSeq NM_023110.2, gi:105990521), FGF8 (MIM\# 600483; RefSeq NM_033163.3, gi:298919216), PROK2 (MIM\# 607002; RefSeq NM_001126128.1, gi:187167260), PROKR2 (MIM\# 607123; RefSeq NM_144773.2, gi:30581162), NELF (MIM\# 608137; RefSeq NM_001130969.1, gi:195972908) [26], CHD7 (MIM\# 608892; RefSeq NM_017780.2, gi:54112402) and WDR11 (MIM\# 606417; RefSeq NM_018117.11, gi:284172506)] were PCR-amplified and screened by direct sequencing. In FGFR1, both exons $8 \mathrm{~A}$ and $8 \mathrm{~B}$, generating isoforms FGFR1-IIIb and FGFR1-IIIc by alternative splicing [27], respectively, were screened. FGFR1 and CHD7 were also analyzed by multiplex ligation-dependent probe amplification assay (MLPA). MLPA was performed according to manufacturer's protocol (Salsa MLPA Kits P133 
Kallmann-2 and P201-B1 CHARGE, MRC-Holland, Amsterdam, the Netherlands). All primer sequences and PCR conditions are available upon request. Nonsense changes resulting in a truncated protein, nucleotide changes affecting splice sites, and frameshifting insertions or deletions were categorized as pathogenic mutations. Missense changes, which were absent from the Single Nucleotide Polymorphism database (http://www.ncbi.nlm. nih.gov/projects/SNP/) and from at least 100 controls from the same geographical region, were identified as possibly pathogenic mutations, and characterized further by functional in vitro studies. Mutations were confirmed from a second PCR product. Mutation nomenclature is according to the guidelines of the Human Genome Variation Society [28] and was verified using the Mutalyzer software (http://www.mutalyzer.nl/2.0/).

This study was performed with appropriate permissions from the Ethics Committee (E7) of the Helsinki University Central Hospital, and from each university hospital in Finland. Written informed consents were obtained from the participants, and also from their guardian if the participant was less than 16 yrs of age.

\section{Site-directed mutagenesis}

$\mathrm{N}$-terminal myc-tagged FGFR1c cDNA in pcDNA3.1+ was used as a template for site-directed mutagenesis using QuikChange II XL site-directed mutagenesis kit (Stratagene, La Jolla, CA). Following mutagenesis, the sequence of the whole plasmid, including the presence of the mutation (G48S, R209H, or E670A), was verified. The myc-tagged FGFR1c cDNA was used for all in vitro studies, as described [5].

\section{Transfections}

All transfections were performed with $300 \mathrm{ng}$ of DNA (50 ng of myc-tagged WT or mutated FGFR1 cDNA and $250 \mathrm{ng}$ of empty vector (EV)) in 24-well plates, using FuGene HD transfection reagent (Roche Diagnostics GmbH, Mannheim, Germany) according to the manufacturer's instructions.

\section{Receptor expression and maturation studies}

For endoglycosidase digestions, sub-confluent COS-1 cells were transiently transfected. 24 h later, cells were washed with phosphate buffered saline (PBS) and lysed with $100 \mu \mathrm{l}$ of radioimmunoprecipitation assay buffer (Sigma, Saint Louis, MO) containing 1X Halt protease inhibitor cocktail (Pierce, Rockford, IL). For deglycosylation analysis, $5 \mu \mathrm{g}$ of protein (Protein Quantification kitRapid (Sigma-Aldrich Chemie GmbH, Buchs, Switzerland)) was subjected to PNGasef and $\mathrm{EndoH}_{\mathrm{f}}$ digestion according to manufacturer's recommendations (New England Biolabs, Ipswich, MA).

\section{Western blot analysis}

Both untreated or endoglycosidase-treated samples were resolved on PAGEr Gold Precast 4-20\% Tris-Glycine
Gels (Lonza, Rockland, ME), and subjected to western blot analysis using an anti-myc antibody (1:1000, clone 4A6, Millipore, Billerica, MA). Immunoreactivity was visualized using Amersham ECL Western blotting detection reagents (GE Healthcare Limited, Buckinghamshire, UK). To control for equal loading, blots were stripped (Restore Western Blot Stripping Buffer (Pierce, Rockford, IL)), and reprobed using anti- $\beta$-actin primary antibody (1:1000, Santa Cruz Biotechnology, Santa Cruz, CA). Overall expression levels were visualized from the PNGase-treated samples, and receptor maturation patterns from the Endo $\mathrm{H}_{\mathrm{f}}$-treated samples. Endoglycosidase experiments were repeated at least three times.

\section{Cell-surface expression}

Cell-surface expression was determined with ELISA technique. Sub-confluent COS-1 cells were transiently transfected, and, 24 h later, washed with PBS, fixed with 4\% paraformaldehyde in PBS for $15 \mathrm{~min}$, and blocked with PBS, containing 1\% bovine serum albumin, for $1 \mathrm{~h}$. Cell-surface expression levels were determined using an anti-myc primary-antibody (see above), HRP-conjugated secondary antibody and assayed using 3,3 ',5,5 'tetramethylbenzidine (Sigma, Saint Louis, MO) as the substrate with detection at $450 \mathrm{~nm}$ following the addition of $0.5 \mathrm{M} \mathrm{H}_{2} \mathrm{SO}_{4}$ [29]. Experiments were performed in triplicate and repeated at least three times.

\section{MAPK signaling studies}

L6 myoblasts were transiently transfected at $10 \%$ confluency. 5 h later, culture medium was replaced with starvation media ( $2 \%$ fetal bovine serum). $20 \mathrm{~h}$ later, the cells were stimulated with FGF2 (Cell Signaling Technology, Danvers, MA), $50 \mathrm{ng} / \mathrm{ml}$ for $0 / 2 / 10 / 30 \mathrm{~min}$. At the indicated time points, the cells were washed with ice-cold PBS and lysed with $50 \mu$ l of radioimmunoprecipitation assay buffer (Sigma, Saint Louis, MO), containing $1 \mathrm{X}$ Halt phosphatase inhibitor cocktail (Pierce, Rockford, IL), and lysates of 3 replicate wells at each time point were pooled for western blot analyses. Samples containing equal amounts of protein $(8 \mu \mathrm{g})$ were resolved as described above, and subjected to western blot analysis using a phospho-p44/42 MAPK (Thr202/ 204) antibody (1:1000, Cell Signaling Technology, Danvers, MA). Immunoreactivity was visualized as described above. To control for equal loading, blots were reprobed using a p44/42 MAPK primary antibody (1:1000, Cell Signaling Technology, Danvers, MA). Experiments were repeated at least three times.

\section{Statistical analyses}

Fisher's exact test was used to determine statistical significance (Simple Interactive Statistical Analysis, SISA, http://www.quantitativeskills.com/sisa/). All $p$-values are two-sided, and $p<0.05$ was considered significant. 


\section{Results}

Minimal estimate of the incidence of KS in Finland

Based on the hospital databases, between 1996 and 2007, altogether $16 \mathrm{KS}$ patients (13 boys and 3 girls) of Finnish origin had been diagnosed in the 5 university Hospitals in Finland. They were born between 1976 and 1987, when altogether 767778 infants were born alive in Finland. Thus, the minimal estimate of the overall incidence of KS was 16/767 778 ( 1 in 48000 newborns). There was a clear difference in estimates between boys (13/392 900; 1 in 30000$)$ and girls (3/374 878; 1 in 125000$)(p=0.02)$.

\section{Molecular genetic and clinical features of KS patients}

Thirty probands ( 25 men and 5 women) participated in the molecular genetic part of our study (mean age 37 yrs, range 13-61 yrs). Two of the men were of other than Finnish origin. Of note, the male-to-female ratio among these participants was not different from that of the patients diagnosed between 1996 and 2007 (see above). Fifteen of the 30 probands (50\%) had at least one relative with cleft lip and/or palate, isolated anosmia, normosmic HH, or KS. All Finnish KS subjects displayed unequivocal anosmia as tested with the 40-item UPSIT test. Overall, 12 of $30(40 \%)$ probands carried a mutation in either FGFR1 (9 probands) or KAL1 (3 probands) (Table 1). No mutations were detected in PROK2, PROKR2, FGF8 or WDR11. Importantly, all 5 women had FGFR1 mutations, in contrast to only 4 of 25 men (Table 1) $(p=0.0009)$. This difference in the prevalence of FGFR1 mutation carriers among men and women affected by KS persisted statistically significant when analyses included only probands of Finnish origin (5 women, $3 / 23$ men) ( $p=0.0006)$, or those of Finnish origin without a KAL1 mutation (5 women, 3/20 men) $(p=0.001)$. No intragenic aberrations were found in MLPA analysis of FGFR1; all the FGFR1 mutations were detected by standard sequencing.

Variable expressivity of FGFR1 mutations was noticed within families (Figure 1). The proband \#11 with a previously reported FGFR1 missense mutation (c.142G > A [p.G48S]) [20], had a severe congenital $\mathrm{HH}$ (see Table $1)$. However, her anosmic father carrying the same mutation had had four children during testosterone therapy, consistent with active spermatogenesis, and her brother had normosmic $\mathrm{HH}$. Also, the associated phenotypes among FGFR1 mutation carriers varied. The proband \#20, and his brother with normosmic $\mathrm{HH}$, had the same missense mutation (c.2009A > C [p.E670A]); the brother also had cleft lip and palate, and limb malformations manifested as a fusion of $3^{\text {rd }}$ and $4^{\text {th }}$ metatarsal bones, and missing of the $2^{\text {nd }}$ and $3^{\text {rd }}$ toe in both feet (see Table 1). In addition, proband \#503 with a frameshift mutation (c.1305_1306dupAT [p.S436YfsX3]) had two children following assisted reproductive techniques,

Table 1 Clinical and molecular genetic features of the probands with Kallmann Syndrome

\begin{tabular}{|c|c|c|c|c|c|c|c|c|c|c|c|}
\hline \multirow[b]{2}{*}{ Proband } & \multirow[b]{2}{*}{ Sex } & \multirow[b]{2}{*}{$\begin{array}{l}\text { Family } \\
\text { history }\end{array}$} & \multicolumn{3}{|c|}{ Mutation } & \multicolumn{3}{|c|}{ History of } & \multicolumn{2}{|r|}{ Olfaction } & \multirow[b]{2}{*}{$\begin{array}{c}\text { Associated phenotypes in } \\
\text { physical examination }\end{array}$} \\
\hline & & & Gene & $\begin{array}{l}\text { Nucleotide } \\
\text { change }\end{array}$ & $\begin{array}{l}\text { Predicted } \\
\text { effect }\end{array}$ & $\begin{array}{l}\text { Micro- } \\
\text { penis }\end{array}$ & $\begin{array}{l}\text { Cryptor- } \\
\text { chidism }\end{array}$ & Puberty & SIT & MRI of OB & \\
\hline 1 & $\mathrm{~F}$ & No & FGFR1 & c.246_247delAG* & $\begin{array}{c}\mathrm{p} . \\
\text { E84Gfs } \times 26\end{array}$ & & & $\mathrm{No}^{\#}$ & A & Absent & A missing tooth \\
\hline 11 & $F$ & $\mathrm{KS}, \mathrm{nHH}$ & FGFR1 & c. $142 \mathrm{G}>\mathrm{A}$ & p.G48S & & & No & A & NA & None \\
\hline 45 & F & Infertility & FGFR1 & c.961_962delAA & $\begin{array}{c}\text { P. } \\
\text { K321RfsX13 }\end{array}$ & & & No & A & $\begin{array}{l}\text { Absent I.dx, } \\
\text { small I.sin }\end{array}$ & None \\
\hline 503 & $\mathrm{~F}$ & KS & FGFR1 & c.1305_1306dupAT & p.S436YfsX3 & & & No & A & Absent & None \\
\hline 54 & $\mathrm{~F}$ & $\mathrm{KS}$ & FGFR1 & c. $1825 \mathrm{C}>\mathrm{T}$ & p.R609X & & & No & A & Absent & $\begin{array}{c}\text { Cleft lip, two missing teeth, } \\
\text { scoliosis }\end{array}$ \\
\hline 13 & M & No & FGFR1 & c.626G > A & p.R209H & Yes & No & No & $A$ & NA & None \\
\hline 14 & M & KS & FGFR1 & c.961_962delAA & $\begin{array}{c}\text { p. } \\
\text { K321RfsX13 }\end{array}$ & NA & No & Partial $^{\S}$ & A & Rudimentary & None \\
\hline 20 & M & $\mathrm{nH} \mathrm{H}^{\mathrm{a}}$ & FGFR1 & C. $2009 A>C$ & p.E670A & Yes & No & No & A & NA & Cleft lip and palate \\
\hline 50 & M & $\mathrm{KS}, \mathrm{nHH}$ & FGFR1 & C. $11 G>A$ & p.W4X & NA & No & No & NA & NA & None \\
\hline 2 & M & KS & $K A L 1$ & g.2357_2360delAgta & & Yes & Bilat & No & A & NA & Synkinesia, a missing tooth \\
\hline 4 & M & KS & $K A L 1$ & c.784C $>\mathrm{T}$ & p.R262X & Yes & Bilat & No & $A$ & NA & $\begin{array}{c}\text { Synkinesia, left renal } \\
\text { agenesis, rheumatoid } \\
\text { arthritis }\end{array}$ \\
\hline 9 & M & $\mathrm{KS}$ & $K A L 1$ & c.471_472delCT & $\begin{array}{c}\text { p. } \\
\text { S158WfsX45 }\end{array}$ & NA & $\mathrm{R}$ & No & A & NA & $\begin{array}{l}\text { Synkinesia, unilateral } \\
\text { conductive hearing loss }\end{array}$ \\
\hline
\end{tabular}

*de novo -mutation; ${ }^{\#}$ Testicular volume less than $4 \mathrm{~mL}$ in males or no spontaneous thelarche in females; ${ }^{5}$ Testicular volume $6 \mathrm{~mL}$ at the age of 33 ; ${ }^{\circ} \mathrm{A}$ brother with normosmic $\mathrm{HH}$, cleft lip and palate, and limb anomalies.

SIT, The Smell Identification Test; OB, olfactory bulbs; $F$, female; $M$, male; $n H H$, normosmic $H H$; $R$, right; $A$, anosmia; $N A$, not assessed FGFR1 MIM\# 136350; RefSeq NM_023110.2, gi:105990521. KAL1 MIM\# 308700; RefSeq NM_000216.2, gi:119395745. 


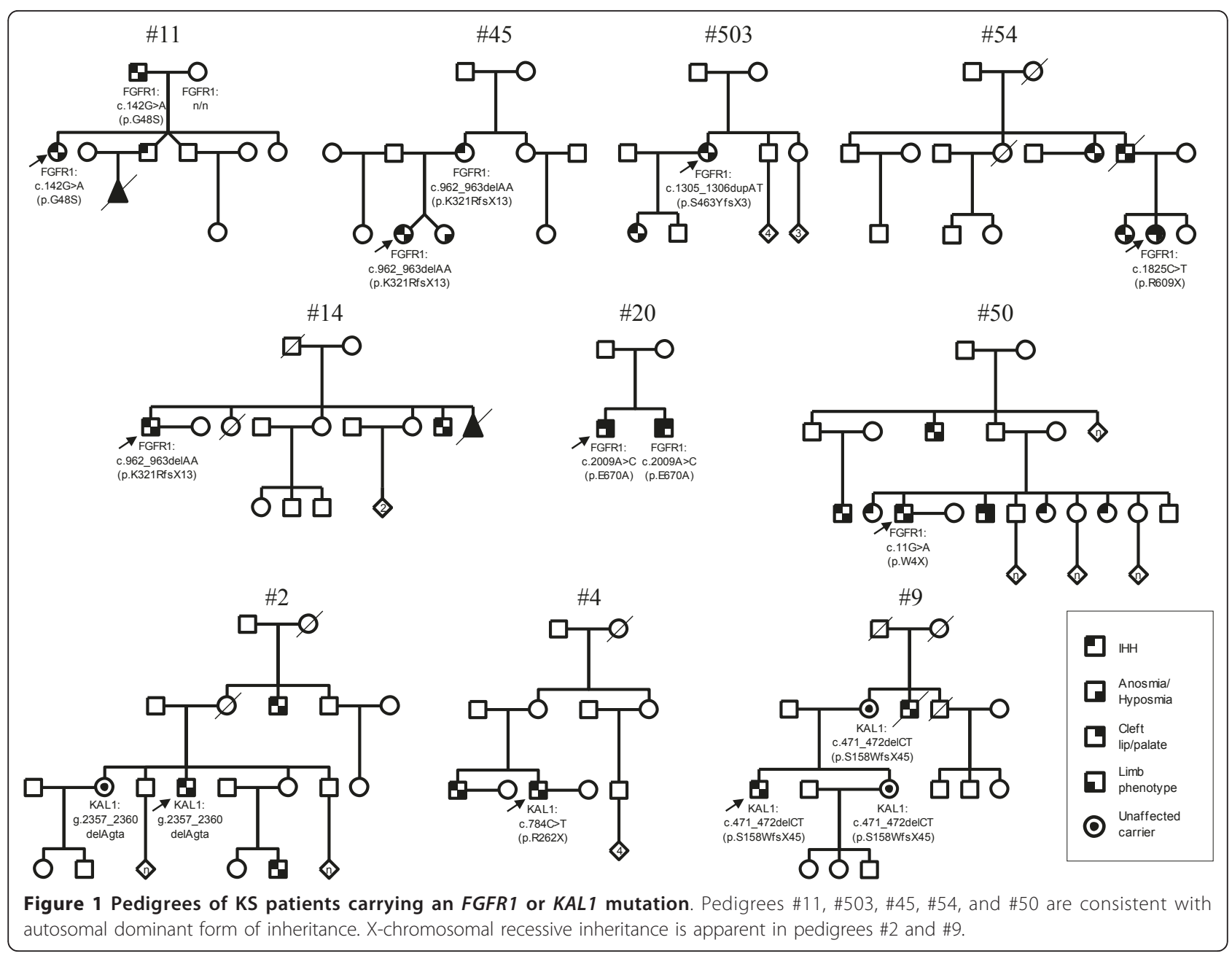

and her daughter also had KS. Proband \#1 was the only proven carrier of de novo FGFR1 mutation. The parents of probands \#13, \#14, \#20, \#50, \#54, and \#503 were unavailable for the mutation analysis.

Three probands had mutations in KAL1 (Table 1). In two pedigrees, the $\mathrm{X}$-chromosomal recessive mode of inheritance was apparent (Figure 1). The sister of the proband \#2, and the mother and the sister of the proband \#9 were all unaffected heterozygous carriers of a KAL1 mutation.

One proband carried a novel missense change in CHD7 (c.7988C > T [p.A2663V), not present in 100 controls. This variant was predicted to be benign by PolyPhen [30] (http://genetics.bwh.harvard.edu/pph/), and it is therefore unlikely that this is a disease-causing mutation. CHD7 was also analyzed by MLPA because intragenic CHD7 deletions have been found in up to $22 \%$ of CHARGE patients [31,32], but none were detected in our KS patients.

In addition, novel missense changes in NELF (c.280 G > A [p.G94S], c.1514 C > T [p.T505M]) were found in probands carrying an FGFR1 mutation (proband \#13: G94S, proband \#54: T505M). However, these were also present in the controls (G94S: 6/100, T505M: 1/100).

\section{Functional characterization of mutant FGFR1s}

To examine the functional consequences of the FGFR1 missense mutations G48S, R209H, and E670A, we compared total and cell-surface expression, receptor maturation, and signaling activities of WT and mutant receptors.

\section{Overall expression and receptor maturation}

Western blot analysis showed two immunoreactive specific bands for wild-type (WT) FGFR1 at approximately $140 \mathrm{kDa}$ and $120 \mathrm{kDa}$ (Figure 2A). Removal of all types of N-linked carbohydrate chains with PNGase digestion reduced the bands into a single one of $\sim 100 \mathrm{kDa}$. The overall expression of the mutant FGFR1s G48S, R209H, and E670A, as judged from the PNGase-treated samples, was not significantly decreased, as compared to WT (Figure 2A, upper panel). Endoglycosidase $\mathrm{H}$ (EndoH $\left.\mathrm{E}_{\mathrm{f}}\right)$ treatment, which removes only high-mannose $\mathrm{N}$-linked 


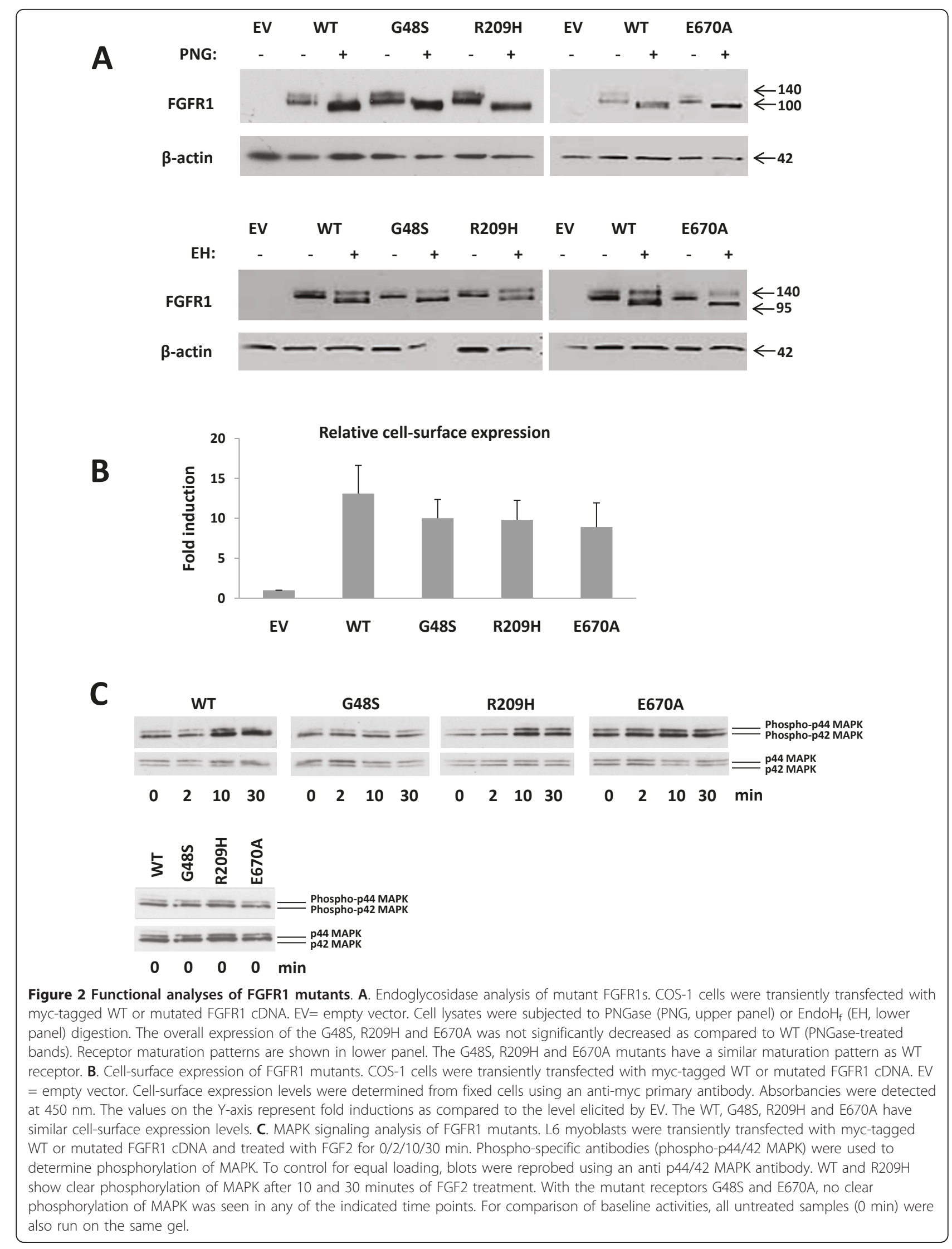


sugars typical for immature forms of the receptor, resulted in similar maturation patterns for G48S, $\mathrm{R} 209 \mathrm{H}$, and E670A, as compared to WT, as only the minor $120 \mathrm{kDa}$ bands changed mobility (Figure 2A, lower panel). This indicates that this minor band represents the partially processed receptor, whereas the 140 $\mathrm{kDa} \mathrm{EndoH}_{\mathrm{f}}$ resistant band represents the fully glycosylated, mature form of FGFR1.

\section{Cell-surface expression}

Cell-surface expression of the WT receptor and the mutants G48S, R209H, and E670A were examined in COS-1 cells. Consistent with the results of deglycosylation experiments, the G48S, R209H, and E670A mutants had similar cell-surface expression levels as WT (Figure 2B).

\section{MAPK signaling}

The signaling activities of the FGFR1 mutants G48S, $\mathrm{R} 209 \mathrm{H}$ and E670A were assayed in L6 myoblasts, a cell line largely devoid of endogenous FGFRs and FGFs [33]. Cells were transfected with WT or mutant FGFR1s, and treated with FGF2 for 0/2/10/30 min. Cells expressing WT receptor showed clear phosphorylation of MAPK after 10 and 30 min of FGF2 treatment (Figure 2C). No ligand-induced phosphorylation of MAPK was seen in cells transfected with G48S and E670A, whereas the R209H responded to FGF2 treatment similarly to WT (Figure 2C). All untreated samples were also run on the same gel, and did not display differences in MAPK phosphorylation, indicating similar baseline activities (Figure 2C).

Features of KS patients without KAL1 or FGFR1 mutations All 18 probands without an identified molecular genetic cause underlying KS were men. A subset of 7 probands had a history of micropenis, and 4 of them also displayed cryptorchidism, consistent with deficient hypothalamic-pituitary-gonadal (HPG) axis activation in fetal life and/or during infancy. Pubertal development was absent in 15 probands, whereas 3 men had displayed partial puberty. In addition, three probands had CHARGE syndrome-associated features. One of them had hypoplastic lateral and superior left semicircular canals, as well as absent right posterior canal (Figure 3). His child had unilateral microphthalmia and bilateral coloboma. The second proband displayed cleft lip and palate, unilateral microphthalmia and coloboma, bilateral hearing impairment, left facial nerve palsy, cupshaped ears, upper body muscular atrophy, and hypoplastic semicircular canals. Thus, he fulfilled the diagnostic criteria for CHARGE syndrome [34]. The third proband also had cup-shaped ears and upper body muscular atrophy; unfortunately, MRI scan was not available. However, none of these 3 probands had mutations in CHD7.

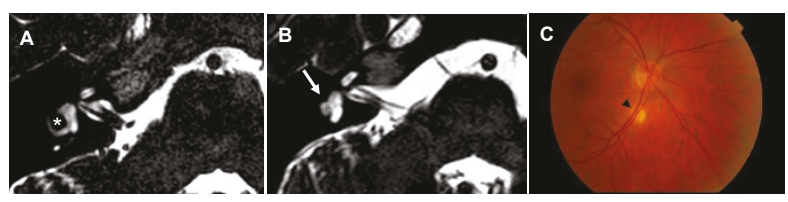

Figure 3 The axial 3D T2-weighted MRI images from the region of the inner ear of $(A)$ a KS patient with normal semicircular canals (asterisk), and (B) a KS patient with hypoplastic semicircular canals (arrow), and an unspecified atrophic area (arrow head) in his retina (C).

\section{Discussion}

Our results show that the nationwide minimal incidence of $\mathrm{KS}$ was approximately 1 in 48000 in Finland. The incidence in men ( 1 in 30 000) was considerably lower than reported among male military conscripts in France (1 in 10 000) [35], and higher than in Sardinia (1 in 84 000) [36]. Military conscript screening, however, may not be the optimal method to ascertain the incidence of $\mathrm{KS}$ because the sense of smell is not typically asked for, and patients with mild reproductive phenotype may escape detection. On one hand, our retrospective study approach - to identify all diagnosed KS cases throughout Finland born during a defined time period - does not account for those who remain undiagnosed with KS due to partial pubertal development or unrecognized hyposmia. On the other hand, the proportion of patients with milder reproductive phenotype is relatively small, because, in Finland, the onset and progression of puberty both in boys and in girls is verified by a general practitioner at school welfare clinics, and those without signs of puberty at an appropriate age are referred to a pediatrician or pediatric endocrinologist. The observed sex difference in our minimal incidence estimate of KS was unlikely due to referral bias. This four-fold incidence in men as compared to women was consistent with the estimates for single tertiary referral centers $[6,8]$. The exact reason for this male predominance is currently unknown. Possible explanations include underdiagnosis in female teenagers, or sex-dependent penetrance of the mutations in unknown KS genes due to either differences in embryonic development or in susceptibility of the HPG axis to disturbances in boys.

In addition to sex-specific difference in the incidence of KS, the molecular genetic diagnoses also differed between sexes. Although FGFR1 mutations are not the sole cause of KS in women worldwide [11,22,23,37], all 5 female probands herein carried an FGFR1 mutation, a proportion significantly higher than in men. A similar sex-specific difference between FGFR1 mutation carriers was also observed among a large series of normosmic $\mathrm{HH}$ patients [5]. From the clinical point of view, KS was passed on to offspring via assisted reproductive techniques in two families, suggesting that all patients with 
congenital $\mathrm{HH}$ undergoing infertility treatment should be offered genetic counseling, similarly as in other situations in which an inherited condition in the family is suspected or detected [38].

All nine identified FGFR1 mutations are located in different domains of the receptor (Figure 4), and four of them were novel (W4X, R209H, E670A, and S436YfsX3). The nonsense mutations W4X, and R609X [39], and the frameshift mutations E84GfsX26 [40], K321RfsX13 [40], and S436YfsX3, all lead to premature stop codons. Both missense mutations G48S [20] and E670A, found in patients with familial KS, displayed impaired downstream signaling as assessed by MAPK phosphorylation. G48S is located in the first immunoglobulin-like domain, which is involved in the receptor autoinhibition, and interacts with the second and the third immunoglobulin -like domains. These interactions alter the affinity for ligand and heparin [41,42]. E670A, located in the intracellular tyrosine kinase domain of the receptor, is anticipated to disrupt autophosphorylation of the TK domain [42]. These results were consistent with loss-of-function. On the other hand, R209H displayed relatively normal MAPK signaling, which suggests that another signaling pathway may be impaired by this mutation.

Overall, $40 \%$ of the probands, a proportion similar to that observed in other populations [20], could be given a molecular genetic diagnosis. In our series, three (12\%) men had KAL1 mutations which all are expected to cause loss-of-function of anosmin-1: both the nonsense mutation R262X [43], and the frameshift mutation S158WfsX45, lead to premature stop codons in the region encoding the first fibronectin type III-like repeat of the protein [44], and the deletion of the last nucleotide of exon 8 and the first three nucleotides of intron 8 (g.2357_2360delAgta) abolishes the splice site, and most likely results in an incorrect transcript. All probands with a KAL1 mutation had severe congenital $\mathrm{HH}$ in

Figure $\mathbf{4}$ Schematic of the FGFR1 mutations at protein level. SP,
signal peptide; D1-D3, immunoglobulin-like domains; TM,
transmembrane domain; JM, juxtamembrane domain; TK1-2, tyrosine
kinase domain (contains two subdomains). The G48S mutation is
located in the first immunoglobulin-like domain (D1), involved in
the receptor autoinhibition. The R209H mutation is located in D2,
responsible for ligand binding and specificity. The E670A mutation
lies within TK2, responsible for activating the MAP (mitogen-
activated protein) kinase pathway. The nonsense mutations, W4X
and R609X, and the frameshift mutations (E84GfSX26, K321RfsX13,
S436YfSX3), all lead to premature stop codons.

combination with synkinesia, and the proband with the $\mathrm{R} 262 \mathrm{X}$ mutation also had renal agenesis.

CHD7 mutation analysis has been suggested for KS patients with CHARGE syndrome-like features [23]. However, patients with $\mathrm{KS}$ or normosmic $\mathrm{HH}$ without suggestive features may also carry $\mathrm{CHD} 7$ mutations $[22,45]$, and even have children with CHARGE syndrome [45]. Thus, CHD7 mutation analysis should be considered for all KS patients. None of our three probands with CHARGE syndrome-like features carried mutations in CHD7, analyzed both by direct sequencing and MLPA, expanding the phenotypic overlap between KS and CHARGE also in patients without CHD7 mutations.

In rare occasions, a congenital $\mathrm{HH}$ patient may carry mutation(s) in more than one $\mathrm{HH}$ gene; Falardeau et al. [11] showed that mutations in FGFR1 and FGF8 synergized to cause severe congenital $\mathrm{HH}$ in a male patient. Also, mutations in NELF have been suggested to modify KS phenotype $[10,12]$, but evidence of its involvement in congenital $\mathrm{HH}$ is not thoroughly convincing. In the current work, none of the patients carried presumably pathogenic mutations in more than one gene (FGFR1 or KAL1). However, two probands with an FGFR1 defect did also harbor novel variants in NELF (G94S and $\mathrm{T} 505 \mathrm{M})$, but given that the incidence of $\mathrm{KS}$ in Finland was 1 in 48000 and these variants were also present in $6 \%$ and $1 \%$ of the controls, it is apparent that these variants are not causing congenital $\mathrm{HH}$. Of note, lack of mutations in PROK2 and PROKR2, now known to cause autosomal recessive $\mathrm{KS}[13,17,37,46]$, probably reflects the unique genetic heritage of the Finnish population [47].

To the best of our knowledge, this is the first study where WDR11 has been analyzed in a series of KS patients after Kim et al. identified this gene by positional cloning of a translocation breakpoint in a KS patient, and discovered heterozygous missense variants in this gene in $6 / 201(3 \%)$ of patients with $\mathrm{KS}$ or normosmic HH [18]. However, we did not detect any mutations, supporting the fact that mutations in WDR11 are rarely involved in congenital $\mathrm{HH}$, at least in the Finnish population.

In contrast to women, the majority of male probands remained without identified mutations, implying the existence of still undescribed gene(s) underlying KS in Finnish men. Indeed, sex-dependent penetrance of the mutations in KS genes yet-to-be discovered could contribute to the higher incidence of KS in men worldwide.

\section{Conclusions}

$\mathrm{KS}$ is a rare condition with a nationwide minimal incidence estimate of 1:48000 in Finland. In Finnish men, mutations were detected in only KAL1 and FGFR1, and 
all women had loss-of-function mutations in FGFR1. Some KS patients without CHD7 mutations display CHARGE syndrome-associated phenotypic features, implying that, in addition to $C H D 7$, there may be other genes associated with both syndromes.

\section{Acknowledgements and Funding}

We wish to thank all the patients and their family members for participating. We also thank all the referring physicians who have helped and devoted their time to this project.

This work was supported by grants from the Helsinki University Central Hospital Research Funds, Academy of Finland, Sigrid Juselius Foundation, Foundation for Pediatric Research, Emil Aaltonen Foundation, Research Foundation of the University of Helsinki, Jalmari and Rauha Ahokas Foundation, Orion-Farmos Research Foundation, Finnish Cultural Foundation, and Novo Nordisk Research Foundation.

\section{Author details}

'Children's Hospital, Helsinki University Central Hospital, University of Helsinki, Fl-00029 Helsinki, Finland. ${ }^{2}$ Institute of Biomedicine, Department of Physiology, Biomedicum Helsinki, University of Helsinki, Fl-00014 Helsinki, Finland. ${ }^{3}$ Helsinki Medical Imaging Center, Helsinki University Central Hospital, Fl-00029 Helsinki, Finland.

\section{Authors' contributions}

EML recruited and phenotyped the patients, performed the statistical analyses, and drafted the manuscript. KV performed most of the molecular genetic analyses, performed the functional analyses, and drafted the manuscript. JT participated in the study design and the molecular genetic analyses, and drafted the manuscript. EE and MT participated in the molecular genetic part of the study. LV planned, provided, and interpreted the MRI analyses. TR carried out the study design, participated in recruiting and phenotyping the patients, and drafted the manuscript. All authors read and approved the final manuscript

\section{Competing interests}

The authors declare that they have no competing interests.

Received: 9 December 2010 Accepted: 17 June 2011 Published: 17 June 2011

\section{References}

1. Schwanzel-Fukuda M, Bick D, Pfaff DW: Luteinizing hormone-releasing hormone (LHRH)-expressing cells do not migrate normally in an inherited hypogonadal (Kallmann) syndrome. Brain Res Mol Brain Res 1989, 6:311-326.

2. Cariboni A, Maggi R: Kallmann's syndrome, a neuronal migration defect. Cell Mol Life Sci 2006, 63:2512-2526.

3. Teixeira L, Guimiot F, Dode C, Fallet-Bianco C, Millar RP, Delezoide AL, Hardelin JP: Defective migration of neuroendocrine GnRH cells in human arrhinencephalic conditions. J Clin Invest 2010, 120:3668-3672.

4. Raivio T, Falardeau J, Dwyer A, Quinton R, Hayes FJ, Hughes VA, Cole LW, Pearce SH, Lee H, Boepple P, Crowley WF Jr, Pitteloud N: Reversal of idiopathic hypogonadotropic hypogonadism. N Engl J Med 2007, 357:863-873.

5. Raivio $T$, Sidis $Y$, Plummer $L$, Chen $H$, Ma J, Mukherjee $A$, JacobsonDickman E, Quinton R, Van Vliet G, Lavoie H, Hughes VA, Dwyer A, Hayes FJ, Xu S, Sparks S, Kaiser UB, Mohammadi M, Pitteloud N: Impaired fibroblast growth factor receptor 1 signaling as a cause of normosmic idiopathic hypogonadotropic hypogonadism. J Clin Endocrinol Metab 2009, 94:4380-4390.

6. Seminara SB, Hayes FJ, Crowley WF Jr: Gonadotropin-releasing hormone deficiency in the human (idiopathic hypogonadotropic hypogonadism and Kallmann's syndrome): pathophysiological and genetic considerations. Endocr Rev 1998, 19:521-539.

7. Jones JR, Kemmann E: Olfacto-genital dysplasia in the female. Obstet Gynecol Annu 1976, 5:443-466.

8. Sedlmeyer IL, Palmert MR: Delayed puberty: analysis of a large case series from an academic center. J Clin Endocrinol Metab 2002, 87:1613-1620.
9. Oliveira LM, Seminara SB, Beranova M, Hayes FJ, Valkenburgh SB, Schipani E, Costa EM, Latronico AC, Crowley WF Jr, Vallejo M: The importance of autosomal genes in Kallmann syndrome: genotype-phenotype correlations and neuroendocrine characteristics. J Clin Endocrinol Metab 2001, 86:1532-1538.

10. Pitteloud N, Quinton R, Pearce S, Raivio T, Acierno J, Dwyer A, Plummer L, Hughes V, Seminara S, Cheng YZ, Li WP, Maccoll G, Eliseenkova AV, Olsen SK, Ibrahimi OA, Hayes FJ, Boepple P, Hall JE, Bouloux P, Mohammadi M, Crowley W: Digenic mutations account for variable phenotypes in idiopathic hypogonadotropic hypogonadism. J Clin Invest 2007, 117:457-463.

11. Falardeau J, Chung WC, Beenken A, Raivio T, Plummer L, Sidis Y, JacobsonDickman EE, Eliseenkova AV, Ma J, Dwyer A, Quinton R, Na S, Hall JE, Huot C, Alois N, Pearce SH, Cole LW, Hughes V, Mohammadi M, Tsai P, Pitteloud N: Decreased FGF8 signaling causes deficiency of gonadotropin-releasing hormone in humans and mice. J Clin Invest 2008, 118:2822-2831.

12. Sykiotis GP, Plummer $L$, Hughes VA, Au M, Durrani $S$, Nayak-Young $S$, Dwyer AA, Quinton R, Hall JE, Gusella JF, Seminara SB, Crowley WF Jr, Pitteloud N: Oligogenic basis of isolated gonadotropin-releasing hormone deficiency. Proc Natl Acad Sci USA 2010, 107:15140-15144

13. Dode C, Teixeira L, Levilliers J, Fouveaut C, Bouchard P, Kottler ML, Lespinasse J, Lienhardt-Roussie A, Mathieu M, Moerman A, Morgan G, Murat A, Toublanc JE, Wolczynski S, Delpech M, Petit C, Young J, Hardelin JP: Kallmann syndrome: mutations in the genes encoding prokineticin-2 and prokineticin receptor-2. PLoS Genet 2006, 2:e175.

14. Franco B, Guioli S, Pragliola A, Incerti B, Bardoni B, Tonlorenzi R, Carrozzo R,

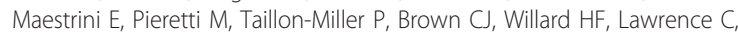
Persico MG, Camerino G, Ballabio A: A gene deleted in Kallmann's syndrome shares homology with neural cell adhesion and axonal pathfinding molecules. Nature 1991, 353:529-536.

15. Legouis R, Hardelin JP, Levilliers J, Claverie JM, Compain S, Wunderle V, Millasseau P, Le Paslier D, Cohen D, Caterina D, Bougueleret L, DlemarreVan Der Wall H, Lutfalla G, Weissenbach J, Petit C: The candidate gene for the X-linked Kallmann syndrome encodes a protein related to adhesion molecules. Cell 1991, 67:423-435.

16. Dode C, Levilliers J, Dupont JM, De Paepe A, Le Du N, Soussi-Yanicostas N, Coimbra RS, Delmaghani S, Compain-Nouaille S, Baverel F, Pecheux C, Le Tessier D, Cruaud C, Delpech M, Speleman F, Vermeulen S, Amalfitano A, Bachelot Y, Bouchard P, Cabrol S, Carel JC, Delemarre-van de Waal H, Goulet-Salmon B, Kottler ML, Richard O, Sanchez-Franco F, Saura R, Young J, Petit C, Hardelin JP: Loss-of-function mutations in FGFR1 cause autosomal dominant Kallmann syndrome. Nat Genet 2003, 33:463-465.

17. Pitteloud N, Zhang C, Pignatelli D, Li JD, Raivio T, Cole LW, Plummer L, Jacobson-Dickman EE, Mellon PL, Zhou QY, Crowley WF Jr: Loss-of-function mutation in the prokineticin 2 gene causes Kallmann syndrome and normosmic idiopathic hypogonadotropic hypogonadism. Proc Natl Acad Sci USA 2007, 104:17447-17452

18. Kim HG, Ahn JW, Kurth I, Ullmann R, Kim HT, Kulharya A, Ha KS, Itokawa Y, Meliciani I, Wenzel W, Lee D, Rosenberger G, Ozata M, Bick DP, Sherins RJ, Nagase T, Tekin M, Kim SH, Kim CH, Ropers HH, Gusella JF, Kalscheuer V, Choi CY, Layman LC: WDR11, a WD protein that interacts with transcription factor EMX1, is mutated in idiopathic hypogonadotropic hypogonadism and Kallmann syndrome. Am J Hum Genet 2010, 87:465-479.

19. Pitteloud N, Acierno JS Jr, Meysing AU, Dwyer AA, Hayes FJ, Crowley WF Jr: Reversible kallmann syndrome, delayed puberty, and isolated anosmia occurring in a single family with a mutation in the fibroblast growth factor receptor 1 gene. J Clin Endocrinol Metab 2005, 90:1317-1322.

20. Trarbach EB, Costa EM, Versiani B, de Castro M, Baptista MT, Garmes HM, de Mendonca BB, Latronico AC: Novel fibroblast growth factor receptor 1 mutations in patients with congenital hypogonadotropic hypogonadism with and without anosmia. J Clin Endocrinol Metab 2006, 91:4006-4012.

21. Pitteloud N, Acierno JS Jr, Meysing A, Eliseenkova AV, Ma J, Ibrahimi OA, Metzger DL, Hayes FJ, Dwyer AA, Hughes VA, Yialamas M, Hall JE, Grant E, Mohammadi M, Crowley WF Jr: Mutations in fibroblast growth factor receptor 1 cause both Kallmann syndrome and normosmic idiopathic hypogonadotropic hypogonadism. Proc Natl Acad Sci USA 2006, 103:6281-6286

22. Kim HG, Kurth I, Lan F, Meliciani I, Wenzel W, Eom SH, Kang GB, Rosenberger G, Tekin M, Ozata M, Bick DP, Sherins RJ, Walker SL, Shi Y, 
Gusella JF, Layman LC: Mutations in CHD7, encoding a chromatinremodeling protein, cause idiopathic hypogonadotropic hypogonadism and Kallmann syndrome. Am J Hum Genet 2008, 83:511-519.

23. Jongmans MC, van Ravenswaaij-Arts CM, Pitteloud N, Ogata T, Sato N, Claahsen-van der Grinten HL, van der Donk K, Seminara S, Bergman JE, Brunner HG, Crowley WF Jr, Hoefsloot LH: CHD7 mutations in patients initially diagnosed with Kallmann syndrome-the clinical overlap with CHARGE syndrome. Clin Genet 2009, 75:65-71.

24. Bianco SD, Kaiser UB: The genetic and molecular basis of idiopathic hypogonadotropic hypogonadism. Nat Rev Endocrinol 2009, 5:569-576.

25. Semple RK, Topaloglu AK: The recent genetics of hypogonadotrophic hypogonadism - novel insights and new questions. Clin Endocrinol (Oxf) 2010, 72:427-435.

26. Miura K, Acierno JS Jr, Seminara SB: Characterization of the human nasal embryonic LHRH factor gene, NELF, and a mutation screening among 65 patients with idiopathic hypogonadotropic hypogonadism (IHH). J Hum Genet 2004, 49:265-268.

27. Miura K, Miura S, Yoshiura K, Seminara S, Hamaguchi D, Niikawa N, Masuzaki $\mathrm{H}$ : A case of Kallmann syndrome carrying a missense mutation in alternatively spliced exon $8 \mathrm{~A}$ encoding the immunoglobulin-like domain IIIb of fibroblast growth factor receptor 1. Hum Reprod 2010, 25:1076-1080.

28. Wildeman M, van Ophuizen E, den Dunnen JT, Taschner PE: Improving sequence variant descriptions in mutation databases and literature using the Mutalyzer sequence variation nomenclature checker. Hum Mutat 2008, 29:6-13.

29. Cheng A, McDonald NA, Connolly CN: Cell surface expression of 5hydroxytryptamine type 3 receptors is promoted by RIC-3. J Biol Chem 2005, 280:22502-22507.

30. Ramensky V, Bork P, Sunyaev S: Human non-synonymous SNPs: server and survey. Nucleic Acids Res 2002, 30:3894-3900.

31. Wincent J, Holmberg E, Stromland K, Soller M, Mirzaei L, Djureinovic T, Robinson $\mathrm{K}$, Anderlid B, Schoumans J: CHD7 mutation spectrum in 28 Swedish patients diagnosed with CHARGE syndrome. Clin Genet 2008, 74:31-38.

32. Wincent J, Schulze A, Schoumans J: Detection of CHD7 deletions by MLPA in CHARGE syndrome patients with a less typical phenotype. Eur $J$ Med Genet 2009, 52:271-272.

33. Newberry EP, Boudreaux JM, Towler DA: The rat osteocalcin fibroblast growth factor (FGF)-responsive element: an okadaic acid-sensitive, FGFselective transcriptional response motif. Mol Endocrinol 1996, 10:1029-1040.

34. Verloes A: Updated diagnostic criteria for CHARGE syndrome: a proposal. Am J Med Genet A 2005, 133A:306-308.

35. Fromantin M, Gineste J, Didier A, Rouvier J: Impuberism and hypogonadism at induction into military service. Statistical study. Prob/ Actuels Endocrinol Nutr 1973, 16:179-199.

36. Filippi G: Klinefelter's syndrome in Sardinia. Clinical report of 265 hypogonadic males detected at the time of military check-up. Clin Genet 1986, 30:276-284.

37. Sarfati J, Guiochon-Mantel A, Rondard P, Arnulf I, Garcia-Pinero A, Wolczynski S, Brailly-Tabard S, Bidet M, Ramos-Arroyo M, Mathieu M, Lienhardt-Roussie A, Morgan G, Turki Z, Bremont C, Lespinasse J, Du Boullay H, Chabbert-Buffet N, Jacquemont S, Reach G, De Talence N, Tonella P, Conrad B, Despert F, Delobel B, Brue T, Bouvattier C, Cabrol S, Pugeat M, Murat A, Bouchard P, Hardelin JP, Dode C, Young J: A comparative phenotypic study of kallmann syndrome patients carrying monoallelic and biallelic mutations in the prokineticin 2 or prokineticin receptor 2 genes. J Clin Endocrinol Metab 2010, 95:659-669.

38. Laitinen EM, Tommiska J, Dunkel L, Sankilampi U, Vaaralahti K, Raivio T: Idiopathic hypogonadotropic hypogonadism in a mother and her monozygotic twins born after a single embryo transfer. Fertil Steril 2010, 93:2074.e13-2074.e16.

39. Riley BM, Mansilla MA, Ma J, Daack-Hirsch S, Maher BS, Raffensperger LM, Russo ET, Vieira AR, Dode C, Mohammadi M, Marazita ML, Murray JC: Impaired FGF signaling contributes to cleft lip and palate. Proc Natl Acad Sci USA 2007, 104:4512-4517.

40. Dode C, Hardelin JP: Kallmann syndrome. Eur J Hum Genet 2009, 17:139-146.

41. Olsen SK, Ibrahimi OA, Raucci A, Zhang F, Eliseenkova AV, Yayon A, Basilico C, Linhardt RJ, Schlessinger J, Mohammadi M: Insights into the molecular basis for fibroblast growth factor receptor autoinhibition and ligand-binding promiscuity. Proc Natl Acad Sci USA 2004, 101:935-940.

42. Groth $\mathrm{C}$, Lardelli M: The structure and function of vertebrate fibroblast growth factor receptor 1. Int I Dev Biol 2002, 46:393-400.

43. Soderlund D, Canto P, Mendez JP: Identification of three novel mutations in the KAL1 gene in patients with Kallmann syndrome. J Clin Endocrinol Metab 2002, 87:2589-2592.

44. Hu Y, Sun Z, Eaton JT, Bouloux PM, Perkins SJ: Extended and flexible domain solution structure of the extracellular matrix protein anosmin-1 by X-ray scattering, analytical ultracentrifugation and constrained modelling. J Mol Biol 2005, 350:553-570.

45. Feret H, McDonald-McGinn DM, Santani A, Zackai EH: Expanding the Phenotypic Overlap Between CHARGE and Kallmann Syndromes due to CHD7 Mutations. (Abstract \#1671). Presented at the 60th Annual Meeting of The American Society of Human Genetics, November 3, 2010, Washington, DC

46. Abreu AP, Trarbach EB, de Castro M, Frade Costa EM, Versiani B, Matias Baptista MT, Garmes HM, Mendonca BB, Latronico AC: Loss-of-function mutations in the genes encoding prokineticin- 2 or prokineticin receptor2 cause autosomal recessive Kallmann syndrome. J Clin Endocrinol Metab 2008, 93:4113-4118.

47. de la Chapelle A: Disease gene mapping in isolated human populations: the example of Finland. J Med Genet 1993, 30:857-865.

\section{doi:10.1186/1750-1172-6-41}

Cite this article as: Laitinen et al: Incidence, Phenotypic Features and Molecular Genetics of Kallmann Syndrome in Finland. Orphanet Journal of Rare Diseases 2011 6:41.

\section{Submit your next manuscript to BioMed Central and take full advantage of:}

- Convenient online submission

- Thorough peer review

- No space constraints or color figure charges

- Immediate publication on acceptance

- Inclusion in PubMed, CAS, Scopus and Google Scholar

- Research which is freely available for redistribution

Submit your manuscript at www.biomedcentral.com/submit
C Biomed Central 